\title{
Improvement of Symbiotic Properties in Rhizobium leguminosarum by Plasmid Transfer
}

\author{
By T. M. DEJONG, ${ }^{1}$ N. J. BREWIN, ${ }^{2}$ A. W. B. JOHNSTON ${ }^{2}$ AND \\ D. A. PHILLIPS ${ }^{1 *}$ \\ ${ }^{1}$ Department of Agronomy and Range Science, University of California, Davis, \\ California 95616, U.S.A. \\ ${ }^{2}$ John Innes Institute, Colney Lane, Norwich NR4 7UH, U.K.
}

(Received 14 September 1981)

\begin{abstract}
Transfer of plasmid pIJ1008, a recombinant of two indigenous Rhizobium leguminosarum plasmids into $R$. leguminosarum strain 300 produced strain 3960 , which reduced significantly more $N_{2}$ in pea root nodules than did strain 300 itself. Strain 3960 was superior to the field isolate $128 \mathrm{C} 53$, from which the symbiotic determinants of pIJ 1008 were derived, and transfer of plasmid pIJ 1008 into two other genetic backgrounds also improved symbiotic performance compared to the introduction of other nodulation plasmids.

As plasmid pIJ1008 carries genetic determinants for an uptake hydrogenase activity $\left(\mathrm{Hup}^{+}\right)$as well as nodulation capability $\left(\mathrm{Nod}^{+}\right)$and other determinants for symbiotic nitrogen fixation $\left(\mathrm{Fix}^{+}\right)$, the increased effectiveness of strains carrying pIJ 1008 may result from their capacity to conserve energy by recovering $\mathrm{H}_{2}$ evolved by nitrogenase.

Intact plant studies with ${ }^{15} \mathrm{~N}$ showed that the superior $\mathrm{N}_{2}$ fixation capability associated with pIJ 1008 was enhanced by $2 \mathrm{~mm}^{-\mathrm{NO}_{3}^{-}}$, a common concentration of soil $\mathrm{N}$. It was also shown that, as plants grew older, the hydrogenase determined by pIJ 1008 was not able to recycle all the hydrogen evolved by pea root nodules.
\end{abstract}

\section{INTRODUCTION}

The traditional method for obtaining Rhizobium strains with favourable symbiotic properties has been the selection of naturally occurring field isolates that produce superior growth of the host legume plant (Vincent, 1974). An alternative technique has been suggested by the demonstration that random mutagenesis of a field isolate can produce strains with enhanced rates of symbiotic $\mathrm{N}_{2}$ fixation (Maier \& Brill, 1978). A third approach might be to construct an improved Rhizobium strain by gene transfer so that symbiotically favourable determinants present in different isolates are combined in a single hybrid strain.

One favourable symbiotic trait is the capacity of some Rhizobium strains to take up $\mathrm{H}_{2}$ (Phelps \& Wilson, 1941; Dixon, 1967). Rhizobium strains that have the $\mathrm{H}_{2}$-uptake system (Hup) form ATP during $\mathrm{H}_{2}$ oxidation (Emerich et al., 1979) and compensate partially for the ATP-dependent evolution of $\mathrm{H}_{2}$ catalysed by the nitrogenase enzyme complex (Bulen \& LeComte, 1966). Thus, Hup ${ }^{+}$Rhizobium strains generally are more effective symbionts than those with Hup ${ }^{-}$phenotypes (Albrecht et al., 1979).

Brewin et al. $(1980 \mathrm{c})$ recently reported that genetic determinants for hydrogenase activity ( $\mathrm{Hup}^{+}$) and nodulation capability $\left(\mathrm{Nod}^{+}\right.$) were co-transferred between $R$. leguminosarum strains during conjugation. The Hup ${ }^{+}$determinants apparently resided on a non-transmissible plasmid, pRL6JI, which was found in R. leguminosarum strain $128 \mathrm{C} 53$ and could be mobilized by recombination with plasmid pVW5JI (Brewin et al., 1982). In the present study the pVW5JI/pRL6JI recombinant plasmid pIJ1008 was transferred into several Hup ${ }^{-}$ 
$R$. leguminosarum strains in order to investigate whether the presence of this plasmid resulted in strains with superior symbiotic properties. Strain $128 \mathrm{C} 53$ has previously been shown to be a relatively efficient $\mathrm{N}_{2}$-fixing symbiont of Alaska peas (Bethlenfalvay et al., 1978) and hence, because the plasmid pIJ 1008 carries many of the symbiotic determinants derived from strain $128 \mathrm{C} 53$ it seemed possible that the transfer of pIJ 1008 to other strains of $R$. leguminosarum might lead to the genetic improvement of these strains. It would however remain an open question whether or not any such improvements were due directly to hydrogenase activity, rather than to some other unspecified symbiotic trait derived from strain $128 \mathrm{C} 53$.

\section{METHODS}

Rhizobium leguminosarum strains and plasmids. Strains and plasmids used are listed in Tables 1 and 2, respectively. Conditions for bacterial culture were described by Beringer (1974). Membrane crosses were described by Beringer et al. (1978). All transmissible plasmids used in this study carried the transposon Tn5, and the transfer of plasmids to recipient strains was monitored by the transfer of the selectable marker kan (kanamycin resistance), which is determined by Tn5. Validity of the constructed strains was checked by analysis of plasmids on agarose electrophoretic gels (Hirsch et al., 1980). The plasmid carrying the Tn5 marker was identified by Southern transfers of plasmid gels to nitrocellulose sheets, followed by hybridization to a radioactively labelled probe DNA containing the transposon Tn5 according to the method of Hombrecher et al. (1981). In addition, the constructed strains were back-crossed to strain 6015 (phe-1, trp-12 rif-392 str-37 nod-6007) (Johnston et al., 1978) and repurified transconjugant clones were tested on peas to confirm that the plasmid-borne markers nod $^{+}, \mathrm{fix}^{+}$and $h^{\prime} p^{+}$were those expected for pVW5JI, pIJ1019 or pIJ1008. Hydrogenase activity was measured as the incorporation of ${ }^{3} \mathrm{H}_{2}$ into pea root nodules (Bethlenfalvay \& Phillips, 1979). All strains of $R$. leguminosarum into which the plasmid pIJ1008 had been introduced formed pea root nodules that took up ${ }^{3} \mathrm{H}_{2}$ at approximately equal rates when assayed $25 \mathrm{~d}$ after inoculation (Brewin et al., 1980 c). The rates were similar to those for $128 \mathrm{C} 53$ itself (data not shown).

The strategy for the strain constructions described in Table 1 was to transfer symbiotic determinants $\left(\mathrm{Nod}^{+} \mathrm{Fix}^{+}\right.$and sometimes $\mathrm{Hup}^{+}$) from two field isolates of $\mathrm{R}$. leguminosarum, namely $128 \mathrm{C} 53$ and 300 , into each of three different recipients, namely 300,3622 and 16015 . Because the symbiotic plasmids pRL6JI and pRL10JI resident in strains $128 \mathrm{C} 53$ and 300 , respectively, were not self-transmissible, their effects on symbiotic performance of other strains could be tested only by recombining in vivo with a transmissible $R$. leguminosarum plasmid such as pVW5JI. The plasmids formed by combining pVW5JI with pRL6JI or pRL10JI. termed pIJ1008 and pIJ1019, respectively (Table 2), were transferred into strains 300, 3622 and 16015 (Table 1). The appropriate control strains 3996 (300 pVW5JI) and B118 (3622 pVW5JI) nodulated peas effectively, but strain 16015 pVW5JI is Nod $^{-}$and $\mathrm{Fix}^{-}$. Thus it was necessary to construct strain 3740, a Nod ${ }^{+}$Fix $^{+}$derivative of 16015 pVW5JI in which the mutant plasmid pIJ 1000 was replaced by pRL10JI, the natural nodulation plasmid of strain 300 (Brewin et al.. 1980a, 1982).

Plant culture. Alaska pea (Pisum sativum L.) plants were grown in a controlled environment chamber under a $14 \mathrm{~h} / 10 \mathrm{~h} \mathrm{light} / \mathrm{dark}$ cycle, $50 \%$ humidity and a photon flux density $(400-700 \mathrm{~nm})$ of $650 \mu \mathrm{E} \mathrm{m}^{-2} \mathrm{~s}^{-1}$. The chamber temperature regime was $20 / 15^{\circ} \mathrm{C}$ during the strain comparisons without combined $\mathrm{N}$ and $21 / 20^{\circ} \mathrm{C}$ during the ontogenetic experiments with strains 3740 and 3894 . The plants were grown in modified 'Leonard jar' assemblies (Leonard, 1943) with either a $\mathrm{N}$-free nutrient solution (DeJong et al., 1981) or the same nutrient solution supplemented to contain $2 \mathrm{mM}-\mathrm{KNO}_{3}$ with 1 atom $\%$ excess ' $\mathrm{N}$. The nutrient solutions were adjusted to $\mathrm{pH} 7.0$ and changed less than $0.5 \mathrm{pH}$ units during the course of the experiments. The complete Leonard jar assemblies were autoclaved before planting. Pea seeds weighing $0.21-0.23 \mathrm{~g}$ and containing $7.2 \pm 0.14 \mathrm{mg} \mathrm{N}$ were surface-sterilized with $95 \%$ ethanol, rinsed and germinated on sterile paper towels with distilled water. After $3 \mathrm{~d}$ imbibition the seedlings were selected for uniformity, planted in Leonard jar assemblies and inoculated with specific Rhizobium strains (Table 1).

Measurements of symbiotic associations. In the strain comparisons without combined $\mathrm{N} 13$ sets of seven plants were inoculated with one of each of the $13 R$. leguminosarum strains listed in Table 1 and were grown with $\mathrm{N}$-free nutrient solution. After $35 \mathrm{~d}$ of growth the plants were harvested. Leaf area was determined with an area meter (LI-3000, Lambda Instruments, Lincoln, Nebr., U.S.A). Leaf dry weight and leaf $\mathrm{N}$ content were determined separately from those of the rest of the plant.

In the ontogenetic experiments plants were inoculated with strain $3740\left(\mathrm{Hup}^{-}\right)$or strain $3894\left(\mathrm{Hup}^{+}\right)$and grown in the presence of either $\mathrm{N}$-free nutrient solution or $2 \mathrm{mM}-\mathrm{KNO}_{3}$ nutrient solution. Seven plants from each treatment were harvested at six intervals starting $11 \mathrm{~d}$ after imbibition (day 11). At each harvest, $\mathrm{C}_{2} \mathrm{H}_{2}$-dependent $\mathrm{C}_{2} \mathrm{H}_{4}$ production (referred to less rigorously as $\mathrm{C}_{2} \mathrm{H}_{2}$ reduction) and $\mathrm{H}_{2}$ evolution were measured on excised root systems (Bethlenfalvay \& Phillips, 1977). Incubation times were $15 \mathrm{~min}$ for $\mathrm{H}_{2}$ evolution and 5 min for $\mathrm{C}_{2} \mathrm{H}_{2}$ 


\section{Table 1. Characteristics of Rhizobium leguminosarum strains studied}

\begin{tabular}{|c|c|c|c|}
\hline $\begin{array}{c}\text { Rhizobium } \\
\text { strain }\end{array}$ & Characters & Symbiotic phenotype & Reference \\
\hline $128 \mathrm{C} 53$ & Field isolate & $\mathrm{Nod}^{+} \mathrm{Fix}^{+} \mathrm{Hup}^{+}$ & Brewin et al. $(1980 c)$ \\
\hline $\begin{array}{r}300 \\
3996 \\
\mathrm{~B} 121 \\
3960\end{array}$ & $\begin{array}{l}\text { Field isolate } \\
300 \text { pVW } 5 J I \\
300 \text { pIJ } 1019 \\
300 \text { pIJ } 1008\end{array}$ & $\begin{array}{l}\text { Nod }^{+} \mathrm{Fix}^{+} \text {Hup }^{-} \\
\text {Nod }^{+} \mathrm{Fix}^{+} \text {Hup }^{-} \\
\text {Nod }^{+} \mathrm{Fix}^{+} \text {Hup }^{-} \\
\text {Nod }^{+} \mathrm{Fix}^{+} \text {Hup }^{+}\end{array}$ & $\begin{array}{l}\text { Johnston \& Beringer (1975) } \\
\text { This study } \\
\text { This study } \\
\text { This study }\end{array}$ \\
\hline $\begin{array}{l}3622 \\
\text { B118 } \\
\text { B } 119 \\
3963\end{array}$ & $\begin{array}{l}\text { Field isolate TOM } \\
3622 \text { pVW } 5 J I \\
3622 \text { pIJ } 1019 \\
3622 \text { pIJ } 1008\end{array}$ & $\begin{array}{l}\text { Nod }^{+} \mathrm{Fix}^{+} \text {Hup }^{-} \\
\text {Nod }^{+} \mathrm{Fix}^{+} \text {Hup }^{-} \\
\text {Nod }^{+} \mathrm{Fix}^{+} \text {Hup }^{-} \\
\text {Nod }^{+} \mathrm{Fix}^{+} \text {Hup }^{+}\end{array}$ & $\begin{array}{l}\text { Brewin et al. }(1980 b) \\
\text { This study } \\
\text { This study } \\
\text { This study }\end{array}$ \\
\hline $\begin{array}{r}16015 \\
3740 \\
3758 \\
3894\end{array}$ & $\begin{array}{l}300 \text { str-37, spc-54, } \Delta(\text { nod fix }) 6007 \\
16015 \text { pVW5JI, pRL10JI* } \\
16015 \text { pIJ1019 } \\
16015 \text { pIJ1008 }\end{array}$ & $\begin{array}{l}\text { Nod }^{-} \\
\text {Nod }^{+} \text {Fix }^{+} \text {Hup }^{-} \\
\text {Nod }^{+} \text {Fix }^{+} \text {Hup }^{-} \\
\text {Nod }^{+} \text {Fix }^{+} \text {Hup }^{+}\end{array}$ & $\begin{array}{l}\text { Brewin et al. }(1980 a) \\
\text { Brewin et al. }(1980 a) \\
\text { This study } \\
\text { Brewin et al. }(1980 c)\end{array}$ \\
\hline
\end{tabular}

*Introduction of pRL10JI eliminated from strain 16015 the corresponding plasmid pIJ1000 (Brewin et al., 1982).

Table 2. Characteristics of Rhizobium leguminosarum plasmids studied

\begin{tabular}{|c|c|c|c|c|}
\hline Plasmid & Description & Markers* & $\begin{array}{l}\text { Approximate } \\
\text { size (MDal) }\end{array}$ & Reference \\
\hline pVW5JI & pRL4JI : :Tn5 & Kan-r, Tra ${ }^{+}$ & 165 & Brewin et al. $(1980 a)$ \\
\hline pRL4JI & Transmissible bacteriocinogenic plasmid & $\mathrm{Med}^{+}, \mathrm{Tra}^{+}$ & 160 & Brewin et al. $(1980 a)$ \\
\hline pRL6JI & Nodulation plasmid of strain $128 \mathrm{C} 53$ & $\mathrm{Nod}^{+}, \mathrm{Fix}^{+}, \mathrm{Hup}^{+}$ & 190 & Brewin et al. $(1980 c)$ \\
\hline pRL10JI & Nodulation plasmid of strain 300 & $\mathrm{Nod}^{+}, \mathrm{Fix}^{+}$ & 220 & Johnston et al. (1981) \\
\hline pIJ 1000 & pRL10JI $\Delta(\operatorname{nod}, f i x)$ & - & 195 & Johnston et al. (1981) \\
\hline pIJ 1008 & pVW5JI/pRL6JI recombinant & $\begin{array}{l}\text { Kan-r, Tra } \\
\text { Fix }^{+}, \text {Hup }^{+}\end{array}$ & 195 & Brewin et al. (1982) \\
\hline pIJ 1019 & pVW5JI/pRL10JI recombinant & Kan-r, Tra ${ }^{+}, \mathrm{Nod}^{+}, \mathrm{Fix}^{+}$ & 155 & Brewin et al. (1982) \\
\hline
\end{tabular}

* Kan-r indicates kanamycin resistance $\left(60 \mu \mathrm{g} \mathrm{ml} \mathrm{m}^{-1}\right)$; $\mathrm{Tra}^{+}$means transmissible by conjugation; $\mathrm{Med}^{+}$ indicates that the plasmid specifies medium bacteriocin; Nod ${ }^{+}$and $\mathrm{Fix}^{+}$refer to nodulation and $\mathrm{N}_{2}$-fixation functions that are absent from $R$. leguminosarum strain 16015; Hup $^{+}$indicates hydrogenase activity $\left({ }^{3} \mathrm{H}_{2}\right.$ incorporation).

reduction. Plant dry weights were determined after $48 \mathrm{~h}$ at $75^{\circ} \mathrm{C}$, and $\mathrm{N}$ content was measured by Kjeldahl analysis with techniques that did not detect $\mathrm{NO}_{3}^{-}$or $\mathrm{NO}_{2}^{-}$(Burris \& Wilson, 1957). The fraction of total $\mathrm{N}$ derived from the $\mathrm{NO}_{3}^{-}$nutrient solution was determined by mass spectrometry using the formula: fraction of plant $\mathrm{N}$ from $\mathrm{NO}_{3}^{-}=\left(\right.$atom $\%$ excess ${ }^{15} \mathrm{~N}$ in plant $) /$ (atom $\%$ excess ${ }^{15} \mathrm{~N}$ in solution).

Strain reisolation. At the conclusion of all experiments rhizobia were reisolated from root nodules and were identified on the basis of intrinsic drug resistance patterns (Josey et al., 1979) to confirm that root nodules had been formed by the appropriate strains. Because derivatives containing pVW5Jl, pIJ 1008 and pIJ1019 had identical drug resistance markers, it was also necessary in some cases to run electrophoretic gels of plasmids to distinguish these derivatives (Hirsch et al., 1980). Two nodules from each of four plants in each treatment were sent by air from California to Norfolk in a desiccated condition suitable for reisolation of Rhizobium. After surface sterilization for $15-30 \mathrm{~s}$ in sodium hypochlorite $(10 \%, \mathrm{w} / \mathrm{v})$, the nodules were rehydrated for $60 \mathrm{~min}$, crushed and streaked for single colonies on plates containing complete medium (tryptone and yeast extract; Beringer, 1974). Five clones per nodule were checked for drug resistance markers and two clones per nodule for electrophoretic profiles of plasmids. 
Table 3. Effects of Rhizobium leguminosarum strains on plant growth and $N$ assimilation

Peas were grown for $35 \mathrm{~d}$ in the absence of combined $\mathrm{N}$ before harvest. Strain 16015 formed no root nodules.

\begin{tabular}{|c|c|c|c|c|}
\hline $\begin{array}{l}\text { Rhizobium } \\
\text { strain }\end{array}$ & $\begin{array}{l}\text { Plant dry weight } \\
\text { (g) }\end{array}$ & $\begin{array}{c}\text { Plant N content } \\
(\mathrm{mg})\end{array}$ & $\begin{array}{l}\text { Leaf area } \\
\left(\mathrm{cm}^{2}\right)\end{array}$ & $\begin{array}{c}\text { N concentration } \\
(\%)\end{array}$ \\
\hline $128 \mathrm{C} 53$ & 4.05 & 138 & 333 & $3 \cdot 4$ \\
\hline 300 & 3.98 & 153 & 339 & 3.8 \\
\hline 3996 & 4.03 & 140 & 315 & $3 \cdot 5$ \\
\hline B 121 & 3.98 & 168 & 363 & $4 \cdot 2$ \\
\hline 3960 & $4 \cdot 58$ & 198 & 386 & $4 \cdot 6$ \\
\hline 3622 & $2 \cdot 00$ & 60 & 170 & $3 \cdot 0$ \\
\hline B 118 & 1.82 & 57 & 159 & $3 \cdot 1$ \\
\hline B119 & 1.07 & 27 & 82 & $2 \cdot 5$ \\
\hline 3963 & 3.75 & 127 & 306 & 3.4 \\
\hline 16015 & 0.53 & 8 & $-^{*}$ & $1 \cdot 5$ \\
\hline 3740 & $3 \cdot 15$ & 104 & 267 & $3 \cdot 3$ \\
\hline 3758 & $2 \cdot 83$ & 114 & 249 & $4 \cdot 0$ \\
\hline 3894 & $3 \cdot 81$ & 173 & 381 & $4 \cdot 6$ \\
\hline L.S.D. $†(0.05)$ & 0.47 & 16 & 46 & 0.2 \\
\hline
\end{tabular}

RESULTS

Effects of transferring various plasmids to different genetic backgrounds

Except in the special case of strain 3740 , none of the introduced plasmids pVW5JI, pIJ1008 or pIJ1019 eliminated any of the resident plasmids from the recipient strains. Therefore, the derivatives of strains 300 and 3622 containing pIJ1008 carried two copies of certain nod and fix genes. It was for this reason that the pIJ 1019 plasmid series was included in the study as an appropriate control for pIJ 1008. Like pIJ 1008, pIJ1019 is a recombinant between pVW5JI and a non-transmissible nodulation plasmid. Unlike pIJ1008, it does not carry the $\mathrm{Hup}^{+}$determinant.

When plasmid pVW5JI was transferred into strains 300 and 3622 , the resulting strains 3996 and B118 maintained the capacity to fix $\mathrm{N}_{2}$, and plant dry weight and $\mathrm{N}$ content associated with these strains were not significantly different from the same parameters measured for plants nodulated by the parent strains 300 and 3622 (Table 3). The transfer of pVW5JI and pRL10JI into strain 16015 produced strain 3740 which also was capable of $\mathrm{N}_{2}$ fixation. Transferring the pVW5JI/pRL10JI recombinant plasmid pIJ 1019 into strains 300 or 16015 to produce strains B121 or 3758 had little effect on symbiotic properties relative to strains 3996 and 3740, respectively, except for a slight increase in $\mathbf{N}_{2}$ fixation. The same plasmid, pIJ1019, however, had a distinctly deleterious effect on symbiotic performance when it was transferred into strain 3622 (see strain B119, Table 3). By contrast plasmid pIJ1008, which carries hup determinants, produced strains with significantly better symbiotic properties than all other related strains. Strains 3960, 3963 and 3894, all of which expressed uptake hydrogenase activity in the ${ }^{3} \mathrm{H}_{2}$ incorporation assay, produced marked increases in plant dry weight and $\mathrm{N}_{2}$ fixation. The plant dry weight, $\mathrm{N}$ content and leaf area produced by strain 3960 were also significantly greater than those of the Hup ${ }^{+}$strain $128 \mathrm{C} 53$, from which the hup determinants in pRL6JI were derived (Table 3). Total plant $\mathrm{N}$ concentration (Table $3)$ was highly correlated with total $\mathrm{N}$ content $(r=0.932, P \leq 0.001)$. 
Table 4. Symbiotic $N_{2}$ fixation in peas nodulated by Rhizobium leguminosarum strain 3740 or 3894 and grown in the absence of combined $N$

Original seed $\mathbf{N}$ content was subtracted from the mean Kjeldahl $\mathbf{N}$ value of at least seven replicate plants on each harvest date.

\begin{tabular}{ccc} 
& \multicolumn{2}{c}{$\mathrm{N}_{2}$ fixed per plant (mg) } \\
\cline { 2 - 2 } & 3740 & 3894 \\
11 & 0 & 0 \\
17 & 2 & 1 \\
23 & 12 & $15^{*}$ \\
30 & 38 & $66^{* * *}$ \\
37 & 74 & $118^{* * *}$ \\
44 & 117 & $202^{* * *}$
\end{tabular}

*,** - Strain effect significant at $P \leq 0.05$ or 0.001 , respectively.

Table 5. $N$ utilization in peas nodulated by Rhizobium leguminosarum strain 3740 or 3894 in the presence of $2 \mathrm{mM}^{-} \mathrm{NO}_{3}^{-}$

Symbiotic $\mathrm{N}_{2}$ fixation was calculated from dilution of ${ }^{15} \mathrm{NO}_{3}^{-}$. Original seed $\mathrm{N}$ content $(7.7 \mathrm{mg})$ was included in total $\mathrm{N}$ values. Values represent the mean of at least seven replicate plants.

\begin{tabular}{|c|c|c|c|c|c|c|c|c|}
\hline \multirow{3}{*}{$\begin{array}{l}\text { Plant age } \\
\text { (d) }\end{array}$} & & & \multicolumn{4}{|c|}{$\mathrm{N}$ utilization $(\mathrm{mg})$} & & \\
\hline & \multicolumn{2}{|c|}{ Total N (mg) } & \multicolumn{2}{|c|}{$\mathrm{N}_{2}$} & \multicolumn{2}{|c|}{ Solution $\mathrm{NO}_{3}^{-}$} & \multicolumn{2}{|c|}{ Symbiotic $\mathrm{N}_{2}$ fixation (\%) } \\
\hline & 3740 & 3894 & 3740 & 3894 & 3740 & 3894 & 3740 & 3894 \\
\hline 11 & 8 & 8 & 0 & 0 & 1 & 1 & 0.0 & 0.0 \\
\hline 17 & 15 & 14 & 4 & $2^{*}$ & 4 & 5 & $26 \cdot 7$ & $14 \cdot 3$ \\
\hline 23 & 31 & $38^{*}$ & 15 & $23^{* * *}$ & 10 & 8 & $48 \cdot 4$ & $60 \cdot 5^{* *}$ \\
\hline 30 & 72 & $119^{* * *}$ & 45 & $90^{* * *}$ & 20 & 22 & $62 \cdot 5$ & $75 \cdot 6^{* * *}$ \\
\hline 37 & 162 & $241^{* * *}$ & 115 & $186^{* * *}$ & 40 & 48 & $71 \cdot 0$ & $77 \cdot 2^{* * *}$ \\
\hline 44 & 239 & $363^{* * *}$ & 165 & $279^{* * * *}$ & 66 & $76^{*}$ & $69 \cdot 0$ & $76 \cdot 8^{*}$ \\
\hline
\end{tabular}

\section{Effect of $\mathrm{NO}_{3}^{-}$on symbiotic properties of strains 3740 and 3894}

A comparison of the Hup ${ }^{-}$and Hup ${ }^{+}$strains 3740 and 3894 produced by plasmid transfer showed that strain 3894 reduced more $\mathrm{N}_{2}$ in root nodules of plants in both the absence and presence of 2 mM-NO$_{3}^{-}$(Tables 4 and 5). Strain 3894 reduced significantly more $\mathrm{N}_{2}$ than strain 3740 during the first $23 \mathrm{~d}$ of growth in both $\mathrm{N}$ treatments $(P \leq 0.05)$. That advantage increased during the remaining $21 \mathrm{~d}$ of the study $(P \leq 0.001)$ (Tables 4 and 5$)$ and within a given $\mathrm{N}$ treatment plants nodulated by strain 3894 had significantly greater dry weight than those nodulated by strain 3740 for the last three harvests (Fig. 1). No significant strain effect on $\mathrm{NO}_{3}^{-}$utilization was detected until the final harvest when plants nodulated by strain 3894 contained more reduced $\mathrm{N}$ from $\mathrm{NO}_{3}^{-}$than plants nodulated by strain 3740 (Table 5). Therefore, the proportion of total reduced $\mathrm{N}$ that was derived from $\mathrm{N}_{2}$ was greater over the last four harvests in plants nodulated by strain 3894 (Table 5).

In general, short-term rates of apparent $\mathrm{N}_{2}$ fixation calculated from $\mathrm{C}_{2} \mathrm{H}_{2}$ reduction and $\mathrm{H}_{2}$ evolution were consistent with the more definitive measures of $\mathrm{N}_{2}$ fixation based on Kjeldahl $\mathrm{N}$ content and ${ }^{15} \mathrm{~N}$ dilution. Plants nodulated by strain 3894 had $\mathrm{C}_{2} \mathrm{H}_{2}$-reduction rates greater than the rates of plants nodulated by strain 3740 in the same $\mathrm{N}$ treatment (Fig. 2). The 


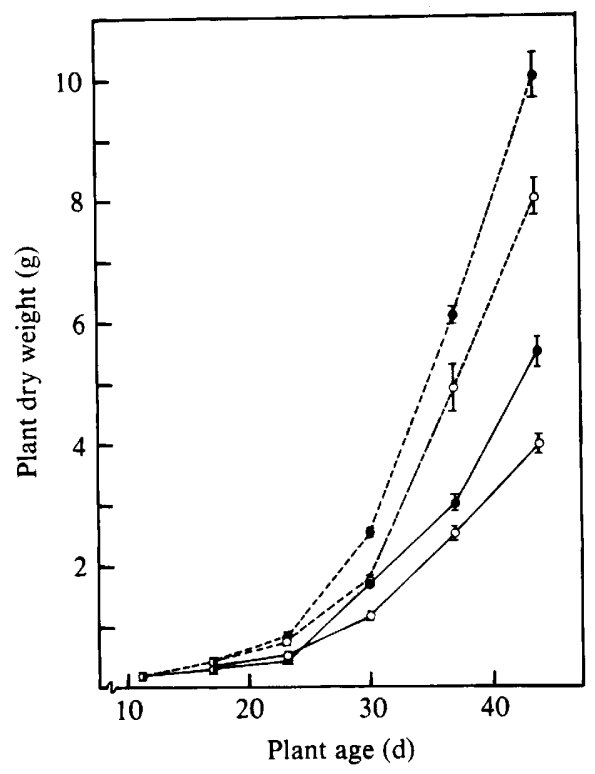

Fig. 1. Dry weight of pea plants nodulated by Rhizobium leguminosarum strain 3740 (O) or 3894 (O) and grown without combined $\mathrm{N}$ (solid line) or with $2 \mathrm{~mm}-\mathrm{NO}_{3}^{-}$(dashed line). Each point and associated vertical bars indicate the mean \pm S.D. for a minimum of seven plants.

2 mM- $\mathrm{NO}_{3}^{-}$treatment increased $\mathrm{C}_{2} \mathrm{H}_{2}$-reduction rates for both Rhizobium strains. $\mathrm{H}_{2}$ evolution from plants nodulated by strain 3894 was lower initially than that associated with strain 3740 in both $\mathbf{N}$ treatments (Fig. 2). As nitrogenase activity increased on a whole plant basis in peas nodulated by strain 3894, however, $\mathrm{H}_{2}$ evolution from that symbiotic association also increased and exceeded the $\mathrm{H}_{2}$ evolved from the 3740 symbiosis. The relative efficiency of $\mathrm{N}_{2}$ fixation, defined by Schubert \& Evans (1976) as $1-\left(\mathrm{H}_{2}\right.$ evolved $/ \mathrm{C}_{2} \mathrm{H}_{2}$ reduced), was greater for $\mathrm{Hup}^{+}$strain 3894 than for Hup ${ }^{-}$strain 3740 at all points assayed (Fig. 2).

\section{Tests for contaminating Rhizobium strains during plant growth experiments}

With a few exceptions Rhizobium cells isolated from root nodules and tested in these experiments had characteristics identical to the original inoculant strains. A small fraction of clones (15-20\%) derived from plants inoculated with strains B121 and 3740 lacked resistance to kanamycin but had the expected patterns of resistance to other drugs. Examination of the plasmid profiles of those kanamycin-sensitive derivatives of B121 and 3740 showed that they differed from the inoculant strains only by the loss of the Tn5-marked plasmids pIJ1019 and pVW5JI, respectively. In all but two of the plants where derivatives of strains B121 or 3740 were reisolated, the majority of clones were still the original B 121 or 3740. The 40 clones tested for each of the other strains showed the expected patterns of drug resistance. None of the plants inoculated with the non-nodulating strain 16015 showed any evidence of root nodules or any significant increase in $\mathbf{N}$ content over that contained in the original seed.

\section{DISCUSSION}

This research clearly demonstrates the potential for increasing the effectiveness of the Rhizobium-legume symbiosis by selective transfer of plasmids. The presence of plasmid pIJ 1008 in strains 3960 and 3963 was associated with $31 \%$ and $128 \%$ increases in $\mathrm{N}_{2}$ 


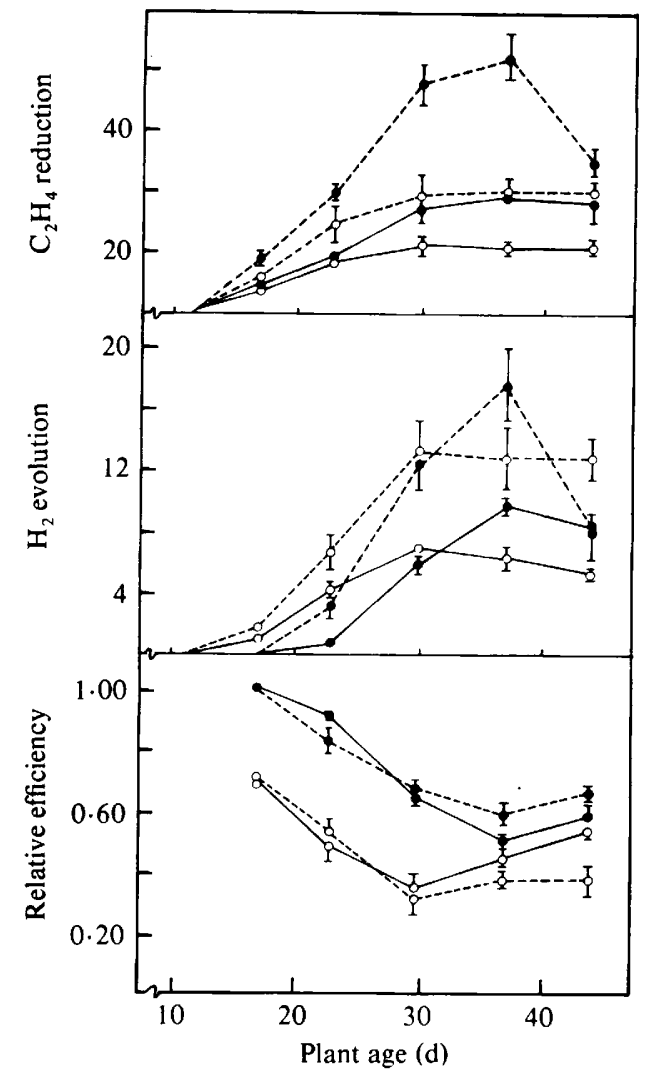

Fig. 2. Ontogenetic changes in $\mathrm{C}_{2} \mathrm{H}_{2}$ reduction, $\mathrm{H}_{2}$ evolution, and relative efficiency of peas nodulated by Rhizobium leguminosarum strain 3740 (O) or 3894 (O) and grown without combined N (solid line) or with $2 \mathrm{mM}^{-\mathrm{NO}_{3}^{-}}$(dashed line). Each point and associated vertical bars indicate the mean \pm S.D. of measurements made on a minimum of seven plants. $\mathrm{H}_{2}$ evolution and $\mathrm{C}_{2} \mathrm{H}_{4}$ reduction were expressed as $\mu \mathrm{mol}$ per plant $\mathrm{h}^{-1}$. Relative efficiency was defined as $1-\left(\mathrm{H}_{2}\right.$ evolved $/ \mathrm{C}_{2} \mathrm{H}_{2}$ reduced $)$.

fixation relative to field isolates 300 and 3622 (calculated after subtracting original seed $\mathrm{N}$ from the values in Table 3). Furthermore, strain 3960 fixed $46 \%$ more $\mathrm{N}_{2}$ than field isolate 128C53, the source of pRL6JI from the $\mathrm{Hup}^{+}$, $\mathrm{Nod}^{+}$and $\mathrm{Fix}^{+}$determinants of pIJ 1008 were derived (Brewin et al., 1980 c). The simplest interpretation of the present study is that the increased effectiveness of the superior strains resulted from their common capacity to recover $\mathrm{H}_{2}$ evolved by nitrogenase. That advantage presumably was associated with the energy conserving nature of the Hup system in Rhizobium bacteroids (Emerich et al., 1979).

Although the simplest explanation of the results shown in Table 3 emphasizes the advantage of $\mathrm{Hup}^{+}$determinants contained in pIJ1008, more complicated explanations cannot be ignored. One such possibility is that the introduction of additional $\mathrm{Nod}^{+}$and $\mathrm{Fix}^{+}$ determinants from strain $128 \mathrm{C} 53$ contributed to the improved performance of strains containing pIJ1008. However, the presence of the nodulation plasmid pIJ1019, which also contains additional $\mathrm{Nod}^{+}$and $\mathrm{Fix}^{+}$determinants, did not enhance the symbiotic performance of strains B 121 or B119 relative to 300 or 3622, respectively. Similarly, in a previous study (DeJong et al., 1981), it was shown that the presence of an additional nodulation plasmid (pRL1JI) also failed to enhance symbiotic $\mathrm{N}_{2}$ fixation by $R$. leguminosarum strain 300 . Thus, the mere presence of a second nodulation plasmid (pIJ 1008) in strains 3960 and 3963 cannot in itself explain their superior symbiotic performance. 
Another explanation might be that different nodulation plasmids may behave differently in various genetic backgrounds. For example, the presence of plasmid pIJ1019 had little effect on symbiotic performance in strain 300 (B121) but had a significant depressive effect in strain 3622 (B119). Similarly, strains 3740 and 3996, which appear to have identical plasmid contents, differ significantly in symbiotic proficiency. Because strain 16015 is a derivative of strain 300 (Brewin et al., 1980a), it seems likely that in the 16015 background one or more of the chromosomal markers, for example $s t r-37$ or $s p c-54$, impaired the overall symbiotic performance of strain 3740 .

The three Hup ${ }^{-}$genetic backgrounds into which pIJ1008 was introduced can thus be graded on the basis of their symbiotic performance on Alaska peas as poor (3622), intermediate (16015) or good (300). In all cases the introduction of pIJ1008 enhanced symbiotic $\mathrm{N}_{2}$ fixation, but the ranking order for the transconjugants remained the same as for the original strains, i.e. the strain 3622 derivative was the worst and the strain 300 derivative was the best (Table 3). It is interesting to note that the degree of enhancement by pIJ1008 was correlated inversely with the previous effectiveness of the recipient strain: i.e. $128 \%$, $70 \%$ and $31 \%$ increases in $\mathrm{N}_{2}$ fixation were observed for strains 3622,16015 (i.e. strain 3740) and 300, respectively. In a previous study (DeJong et al., 1981), the nodulation plasmids from three strains, which could be graded for symbiotic performance as poor (3622), intermediate (248) or good (300) were transferred into a single recipient strain (16015) of intermediate capability. The 16015 derivatives containing those nodulation plasmids ( $p$ RL5JI, pRL1JI and pRL10JI, respectively) were indistinguishable from each other in symbiotic performance, suggesting in those cases that the introduced plasmids were less important in determining symbiotic performance than was the genetic background of the host strain. By contrast, in the present study both the introduced plasmid (pIJ1008) and the genetic background of the host strain made a significant contribution to the overall level of symbiotic $\mathrm{N}_{2}$ fixation with Alaska peas.

The identical dry weights and the similar rates of $\mathrm{C}_{2} \mathrm{H}_{2}$ reduction of plants grown on $\mathrm{N}$-free solution up to day 23 (Figs 1 and 2) suggest that strains 3740 and 3894 do not differ significantly in the rate at which they form nodules on Alaska pea seedlings. The differences between the plants grown on $\mathrm{N}$-free solution and those supplied with $2 \mathrm{mM}^{-} \mathrm{NO}_{3}^{-}$are consistent with the known importance of combined $\mathrm{N}$ during seedling development in this system (DeJong \& Phillips, 1981). Alleviating the $\mathrm{N}$ stress during early seedling growth promoted symbiotic $\mathrm{N}_{2}$ fixation and plant growth in plants nodulated with either strain. The most critical fact revealed by data in Table 5 is that the superior $\mathrm{N}_{2}$ fixation capability associated with pIJ 1008 was enhanced by the availability of 2 mM-NO- ${ }_{3}^{-}$, a concentration of nitrate commonly found in field soil solutions (Russell, 1973). The promotion of $\mathrm{N}_{2}$ fixation in strain 3894 relative to 3740 was significant both on an absolute basis $(P \leq 0.001)$ and on a relative basis expressed as percentage of total plant $\mathrm{N}$ from $\mathrm{N}_{2}(P \leq 0.05)$ because strain 3894 had little effect on $\mathrm{NO}_{3}^{-}$utilization until the final harvest (Table 5).

The data obtained from plants nodulated by $\mathrm{Hup}^{-}$strain 3740 or $\mathrm{Hup}^{+}$strain 3894 indicate that the Hup system in these strains was not efficient enough to recover all $\mathrm{H}_{2}$ evolved by nitrogenase. The relative efficiency values in plants nodulated with strain 3894 were near 1.0 only when root nodules were first formed and decreased to as low as 0.5 in some plants at later stages (Fig. 1). Schubert et al. (1977) reported that Hup ${ }^{+}$soybean and cowpea rhizobia maintained relative efficiencies near 1.0 for over 4 weeks. Previous research with the $\mathrm{Hup}^{+}$strain $128 \mathrm{C} 53$ also showed ontogenetic changes in the relative rates of $\mathrm{H}_{2}$ evolution and ${ }^{3} \mathrm{H}_{2}$ incorporation (Bethlenfalvay \& Phillips, 1979).

This work indicates that both the quantity of plant biomass produced and the $\mathrm{N}$ content of that biomass can be increased by selective transfer of plasmids into strains of $R$. leguminosarum. In most cases the introduced plasmids were stably maintained in the recipient strains even after one passage through pea root nodules. Because not all $\mathrm{H}_{2}$ evolved by nitrogenase was recovered by the Hup system determined on pIJ1008, additional 
opportunities exist for identifying superior Hup systems that can be transferred to $R$. leguminosarum. It will be of interest to test whether plasmid-borne hup determinants eventually may be used to insert Hup systems into $R$. meliloti and $R$. trifolii since no reproducible, significant ${ }^{3} \mathrm{H}_{2}$-incorporation activity has been measured in those organisms which nodulate the important forage crops alfalfa and clover, respectively.

This research was supported in part by NATO Research Grant 1533 and National Science Foundation Grants PFR 77-07301 and PCM 78-01146. We acknowledge the technical assistance of S. S. Jue and E. A. Wood and thank G. Hombrecher for performing the Tn5 hybridizations.

\section{REFERENCES}

Albrecht, S. L., MaIER, R. J., Hanus, F. J., Russell, S. A., EMERICh, D. W. \& Evans, H. J. (1979). Hydrogenase in Rhizobium japonicum increases nitrogen fixation by nodulated soybeans. Science 203, 1255-1257.

BERINGER, J. E. (1974). R factor transfer in Rhizobium leguminosarum. Journal of General Microbiology 84, 188-198.

Beringer, J. E., Hoggan, S. A. \& Johnston, A. W. B. (1978). Linkage mapping in Rhizobium leguminosarum by means of $\mathbf{R}$ plasmid-mediated recombination. Journal of General Microbiology 104, 201-207.

Bethlenfalvay, G. J. \& Phillips, D. A. (1977). Ontogenetic interactions between photosynthesis and symbiotic nitrogen fixation in legumes. Plant Physiology 60, 419-421.

Bethlenfalvay, G. J. \& Phillips, D. A. (1979). Variation in nitrogenase and hydrogenase activity of Alaska pea root nodules. Plant Physiology 63, $816-820$.

Bethlenfalvay, G. J., Abu-Shakra, S. S. \& PHILliPS, D. A. (1978). Interdependence of nitrogen nutrition and photosynthesis in Pisum sativum L. II. Host plant response to nitrogen fixation by Rhizobium strains. Plant Physiology 62, 131-134.

BrewiN, N. J., BERINGER, J. E., BUCHANANWollaston, A. V., Johnston, A. W. B. \& Hirsch, P. R. $(1980 a)$. Transfer of symbiotic genes with bacteriocinogenic plasmids in Rhizobium leguminosarum. Journal of General Microbiology 116, 216-270.

Brewin, N. J., Beringer, J. E. \& Johnston, A. W. B. $(1980 b)$. Plasmid mediated transfer of host-range specificity between two strains of Rhizobium leguminosarum. Journal of General Microbiology 120, 413-420.

Brewin, N. J., DeJong, T. M., Phillips, D. A. \& JohNSTON, A. W. B. $(1980 c)$. Co-transfer of determinants for hydrogenase activity and nodulation ability in Rhizobium leguminosarum. Nature, London 288, 77-79.

Brewin, N. J., Wood, E. A., Johnston, A. W. B., DibB, N. J. \& Hombrecher G. (1982). Recombinant nodulation plasmids in Rhizobium leguminosarum. Journal of General Microbiology 128, 1817-1827.

Bulen, W. A. \& Lecomte, J. R. (1966). The nitrogenase system from Azotobacter: two enzyme requirements for $\mathrm{N}_{2}$ reduction, ATP-dependent $\mathrm{H}_{2}$ evolution, and ATP hydrolysis. Proceedings of the National Academy of Sciences of the United States of America 56, 979-986.

BURRIS, R. H. \& Wilson, P. W. (1957). Methods for measurement of nitrogen fixation. Methods in Enzymology 4, 355-366.

DeJong, T. M., Brewin, N. J. \& Phillips, D. A. (1981). Effect of plasmid content in Rhizobium leguminosarum on symbiosis and host plant functions. Journal of General Microbiology 124, 1-7.

DeJong, T. M. \& Phillips, D. A. (1981). Nitrogen stress and apparent photosynthesis in symbioticallygrown Pisum sativum L. Plant Physiology 68, 309-313.

Dixon, R. O. D. (1967). Hydrogen uptake and exchange by pea root nodules. Annals of Botany 31, $179-188$.

Emerich, D. W., Ruiz-Argüeso, T., Ching, T. M. \& Evans, H. J. (1979). Hydrogen-dependent nitrogenase activity and ATP formation in Rhizobium japonicum bacteroids. Journal of Bacteriology 137, 153-160.

HiRsch, P. R., Johnston, A. W. B., Brewin, N. J., Van Montagu, M. \& Schell, J. (1980). Physical identification of bacteriocinogenic, nodulation and other plasmids in strains of Rhizobium leguminosarum. Journal of General Microbiology 120, 403-412.

Hombrecher, G., Brewin, N. J., \& Johnston, A. W. B. (1981). Linkage of genes for nitrogenase and nodulation ability on plasmids in Rhizobium leguminosarum and $R$. phaseoli. Molecular and General Genetics 182, 133-136.

JohNSTON, A. W. B. \& BERINGER, J. E. (1975). Identification of the Rhizobium strains in pea root nodules using genetic markers. Journal of General Microbiology 87, 343-350.

JohNSTON, A. W. B., BEYNON, J. L., BUCHANANWollaston, A. V., Setchell, S. M., Hirsch, P. R. \& BERINGER, J. E. (1978). High frequency transfer of nodulating ability between strains and species of Rhizobium. Nature, London 276, 635-636.

Johnston, A. W. B., Hombrecher, G., Brewin, N. J., \& COOPER, M. C. (1982). Two transmissible plasmids in Rhizobium leguminosarum strain 300 . Journal of General Microbiology 128, 85-93.

Josey, D. P., Beynon, J. L., Johnston, A. W. B. \& BERINGER, J. E. (1979). Strain identification in Rhizobium using intrinsic antibiotic resistance. Journal of Applied Bacteriology 46, 343-350. 
LEONARD, L. T. (1943). A simple assembly for use in testing of cultures of rhizobia. Journal of Bacteriology 45, 523-527.

MAIER, R. J. \& BRILL, W. J. (1978). Mutant strains of Rhizobium japonicum with increased ability to fix nitrogen for soybean. Science 201, 448-450.

Phelps, A. S. \& Wilson, P. W. (1941). Occurrence of hydrogen in nitrogen-fixing organisms. Proceedings of the Society of Experimental Biology and Medicine 47, 473-476.

Russell, E. W. (1973). Soil Conditions and Plant Growth. New York: Longman.
Schubert, K. R., Engelke, J. A., Russell, S. A. \& EvaNs, H. J. (1977). Hydrogen reactions of nodulated leguminous plants. I. Effect of rhizobial strain and plant age. Plant Physiology 60, 651-654.

SCHuBERT, K. R. \& EvaNs, H. J. (1976). Hydrogen evolution: a major factor affecting the efficiency of nitrogen fixation in nodulated symbionts. Proceedings of the National Academy of Sciences of the United States of America 73, 1207-1211.

VINCENT, J. M. (1974). Root-nodule symbiosis with Rhizobium. In The Biology of Nitrogen Fixation, pp. 265-341. Amsterdam: North Holland. 